\title{
Spontaneous Pneumomediastinum without
Pneumothorax in Non-ventilated COVID-19
Pneumonia: A Case Report
}

Invazif-Non-Invazif Ventilasyon Uygulanmayan COVID-19 Pnömonisinde Pnö-
motoraks Olmadan Spontan Pnömomediastinum: Olgu Sunumu

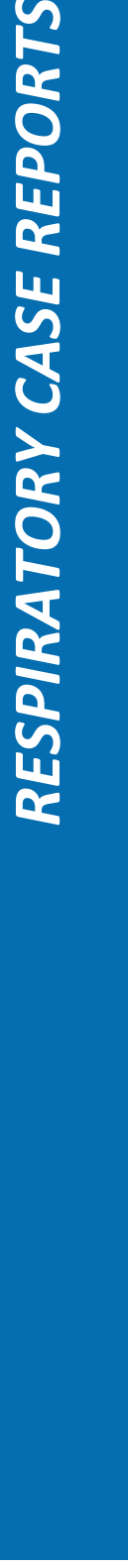

\section{Abstract}

Spontaneous pneumomediastinum (SPM) is among the rare complications of Coronavirus Disease-19 (COVID-19) and usually involves patients with a severe form of disease who are undergoing treatment with invasive/non-invasive ventilation or high-flow oxygen therapy. A very low percentage of SPM cases are detected in non-ventilated COVID-patients, the underlying causes of which are still to be understood. We report here on the case of a 65-year-old patient with no clinical history of cardiovascular or pulmonary disease who developed SPM within a few days following hospital admission. SPM was detected on chest CT-angiography, and was unrelated to highflow oxygen treatment.

Key words: COVID-19, Spontaneous pneumomediastinum, SARS-CoV-2.

\section{Özet}

Spontan pnömomediastinum (SPM) korona virüs (COVID-19) hastalığının nadir komplikasyonları arasında bulunmaktadır. Genellikle invazif / noninvazif ventilasyon veya yüksek akışlı oksijen tedavisi alan ve hastalığı ağır şekilde geçirmekte olan hastalarda görülür. Ventilasyon kullanılmayan COVID-19 hastalarında çok düşük oranda SPM tespit edilmektedir. Ancak SPM gelişmesinin altında yatan nedenler hala tam olarak anlaşılmamıştır. Bu makalede 65 yaşında, klinik olarak kardiyovasküler veya pulmoner hastalık geçmişi olmayan, hastaneye yatışından sonraki birkaç gün içinde SPM gelişen bir olguyu sunmaktayız. Toraks BT-anjiyografisinde SPM tespit edilmiş olup yüksek akımlı oksijen tedavisi kullanmamıştır.

Anahtar Sözcükler: COVID-19, spontan pnömomediastinum, SARS-CoV-2.

\begin{tabular}{|c|c|}
\hline $\begin{array}{l}\text { 'Department of Translational Medicine, University of Ferrara, Fer- } \\
\text { rara, Italy } \\
{ }^{2} \text { Medical Department, Unit of Internal Medicine, Ospedale } \\
\text { "m.bufalini", Cesena, Italy }\end{array}$ & $\begin{array}{l}\text { 'Translasyonel Tıp Bölümü, Ferrara Üniversitesi, Ferrara, } \\
\text { İtalya } \\
{ }^{2 T ı p ~ D e p a r t m a n ı, ~ D a h i l i y e ~ B i r i m i, ~ O s p e d a l e ~ " m . b u f a l i n i ", ~} \\
\text { Cesena, İtalya }\end{array}$ \\
\hline
\end{tabular}

Submitted (Başvuru tarihi): 10.06.2021 Accepted (Kabul tarihi): 16.07.2021

Correspondence (iletişim): Elisa Paolucci, Department of Translational Medicine, University of Ferrara, Ferrara, Italy

e-mail: elisa.paolucci@auslromagna.it 
As of May 2021, more than 133 million confirmed coronavirus cases have been reported in 220 countries around the world, along with more than 3 million deaths. Coronavirus Disease-19 (COVID-19), the clinical manifestation of Severe Acute Respiratory Syndrome Coronavirus-2 (SARS-CoV-2) infection(1), is known to present with a wide range of symptoms and signs, such as fever, cough, dyspnoea, myalgias and asthenia, as well as digestive symptoms, although in most cases the course of infection is asymptomatic.

ARDS (Acute Respiratory Distress Syndrome) is the main cause of death, usually following a hyperinflammatory state, and develops rapidly in $5 \%$ of patients with coronavirus infection $(2,3)$. The RT-PCR (reverse transcriptionpolymerase chain reaction) detection of SARS-CoV-2 mRNA is the standard approach for in-hospital and outhospital diagnosis, although in recent months CT scans have been used as a fundamental tool not only for diagnosis, but also for measuring the extent of the compromised parenchyma in COVID patients $(4,5)$. Chest CT scans, together with laboratory inflammatory markers, can help clinicians decide upon an appropriate therapy, and $C T$ examinations, in particular, may be useful for revealing some atypical signs that would not otherwise be detectable from a physical examination. Up to $1 \%$ of COVID patients have been stated to develop spontaneous pneumothorax (6), while spontaneous pneumomediastinum (SPM) is a rarer complication, remaining anecdotic, and has been described in only a few reports $(7,8)$. SPM, defined as an air-flap in the mediastinum that is not associated with trauma, is a well-known complication in many infections of the lung (9-11), and is often associated with pneumothorax and/or subcutaneous emphysema, resulting from alveolar rupture, and often occurs secondary to acute increases in intrathoracic pressure.

Common causes include exercise, drugs, asthma, vomiting or Valsalva maneuvers. It is rarely benign and selflimited, and is more prevalent in young males. Typical symptoms include the triad of pneumomediastinum, being thoracic pain, dyspnea and subcutaneous emphysema. Hamman's sign, being crepitus heard on auscultation of the heart, is a common finding, and may be the only abnormal physical finding (12). A physical examination is often insufficient for a diagnosis of SPM, with a need for CT scans for confirmation. Released alveolar air dissects centripetally through the pulmonary interstitium along the bronchovascular sheaths, toward the pulmonary hila and into the mediastinum, which is a pathophys- iological mechanism that was described by Macklin et al. in 1944, and is known as the Macklin effect (13).

High-flow oxygen therapy, when supplied, increases the risk of complications, such as those cited above; while CPAP, NIV and HFNC increase intra-alveolar pressure, and considering that acute lung deterioration with rapid desaturation is per se a reason favouring alveolar rupturing, it is easy to understand how severe forms of pneumonia treated with high-flow oxygen therapy can result in poor outcomes.

We report here on the case of a 65 -year-old male who developed SPM after being hospitalized for COVID-19, even without receiving high-flow or high-pressure oxygen therapy.

\section{CASE}

In April 2021, a 65-year-old male presented to the emergency ward of M. Bufalini Hospital in Cesena, Italy, with a 10-day history of fever, dry cough and diarrhoea, and was subsequently diagnosed with SARS-CoV-2 infection after a RT-PCR detection of viral mRNA on a nasopharyngeal swab.

He was a non-smoker with a history only of celiac disease, and had been on no drug-therapy prior to hospital admission. Upon arrival, he was awake, alert and oriented, with a body temperature of $36^{\circ} \mathrm{C}$, respiratory rate of 30 breaths per minute, blood pressure $125 / 70 \mathrm{mmHg}$, pulse 92 beats per minute and arterial oxygen saturation (SpO2) $90 \%$ at rest. The Modified Early Warning Score (MEWS), calculated at the time of admission, was 3, while the National Early Warning Score (NEWS) score was 6 . Both scores were calculated to assess the patient's clinical stability (14).

The patient was placed on low-flow oxygen therapy through a non-rebreather mask, despite no signs of respiratory fatigue being reported. An arterial blood sample examination and routine blood tests were performed, the former of which revealed respiratory insufficiency with a $\mathrm{PaO}_{2} / \mathrm{fiO}_{2}$ ratio of 296 , while the latter showed increased serum LDH (384 U/L) and CPK (479 U/L), neutrophilic leukocytosis (WBC 12500/mmc, N 11500/mmc) with lymphopenia (L 600/mmc) and high serum CRP (15.7 $\mathrm{mg} / \mathrm{dl}$ ). Urinary antigen testing for $\mathrm{L}$. pneumophila and $\mathrm{S}$. pneumoniae was negative, as were the blood cultures. Table 1 presents a summary of the blood test results during the patient's hospital stay.

Table 1: Laboratory exams of patient during hospitalization 


\begin{tabular}{|c|c|c|c|c|c|c|}
\hline & Day 1 & Day 2 & Day 7 & Day 11 & Day 13 & Range \\
\hline WBC (n/mmc) & 12510 & & 11620 & 13340 & 9370 & $4000-10000$ \\
\hline $\mathrm{RBC}\left(\mathrm{n}^{*} 106 / \mathrm{mmc}\right)$ & 4.62 & & 5.12 & 5.19 & 4.83 & $4.50-5.70$ \\
\hline $\mathrm{Hb}(\mathrm{g} / \mathrm{dl})$ & 15.1 & & 16.5 & 17.1 & 15.8 & $13.50-17.00$ \\
\hline Hct (\%) & 44 & & 50 & 48 & 45 & $40-52$ \\
\hline MCV (fl) & 94 & & 97 & 92 & 92 & $80-95$ \\
\hline $\mathrm{MCHC}(\%)$ & 34.6 & & 33.3 & 36 & 35 & $32-36$ \\
\hline Neutrophiles ( $\mathrm{n} / \mathrm{mmc}$ ) & 11510 & & 8200 & 10770 & 6490 & $2000-8000$ \\
\hline Lymphocytes (n/mmc) & 600 & & 2540 & 1470 & 1960 & $1000-4000$ \\
\hline Monocytes (n/mmc) & 370 & & 810 & 790 & 860 & $200-1000$ \\
\hline Eosinophils (n/mmc) & 0 & & 10 & 290 & 50 & $0-500$ \\
\hline Basophils ( $\mathrm{n} / \mathrm{mmc}$ ) & 200 & & 60 & 20 & 10 & $0-20$ \\
\hline Platelets (n/mmc) & 207000 & & 464000 & 354000 & 214000 & $150000-450000$ \\
\hline Creatinine $(\mathrm{mg} / \mathrm{dl})$ & 0.88 & 0.83 & & 0.68 & 0.75 & $0.70-1.20$ \\
\hline eGFR (ml/min) & 90 & 92 & & 100 & 96 & $>90$ \\
\hline Azote (mg/dl) & 24 & & & & & $<71$ \\
\hline Tot bilirubin (mg/dl) & 0.36 & & & 0.6 & & $<1.20$ \\
\hline Direct bilirubin (mg/dl) & 0.2 & & & 0.2 & & $<0.30$ \\
\hline Sodium (mmol/l) & 132 & 138 & 138 & 135 & 134 & $136-145$ \\
\hline Potassium (mmol/l) & 3.8 & 4.8 & 4.5 & 4.3 & 4.4 & $3.5-5.1$ \\
\hline Chlorine (mmol/l) & 95 & & & & & $98-107$ \\
\hline Calcium (mg/dl) & & & & & 9.5 & $8.6-10.2$ \\
\hline AST (U/L) & 43 & & & & & $<40$ \\
\hline ALT (U/L) & 25 & & & 88 & & $<41$ \\
\hline GGT (U/L) & & & & 33 & & $8-61$ \\
\hline CPK (U/L) & & 479 & & & & $30-240$ \\
\hline LDH (U/L) & 384 & & & & & $135-225$ \\
\hline Troponin T (ng/ml) & 9 & & & & & $<15$ \\
\hline C-Reactive Protein (mg/dl) & 15.7 & 20.5 & 1.6 & & & $<0.5$ \\
\hline PT (INR) (ratio) & 1.1 & & & & & $0.80-1.20$ \\
\hline aPTT (ratio) & 0.93 & & & & & $0.80-1.20$ \\
\hline D-dimer (ng/ml) & 440 & & & & & $<500$ \\
\hline Quantiferon & & Negative & & & & Negative \\
\hline IL-6 (pg/ml) & & 116 & & & & $<5.9$ \\
\hline Ferritin (mg/dl) & & 1390 & & & & $30-400$ \\
\hline Procalcitonin (ng/ml) & & 0.24 & & & & $<0.5$ \\
\hline
\end{tabular}

WBC $=$ White Blood Cells; RBC = Red Blood Cells; Hb= Haemoglobin; Hct= Hematocrit; MCV= Medium Corpuscular Volume; MCHC $=$ Mean Corpuscular Haemoglobin Concentration; eGFR= estimated Glomerular Filtration Rate; AST= Aspartate Transferase; ALT= Alanine Transferase; GGT= Gamma Glutamyl Transpeptidase; CPK= Creatine Phosphokinase; $L D H=$ Lactic Dehydrogenase; PT= Prothrombin Time; aPTT= activated Partial Thromboplastin Time; IL-6= Interleukin-6 


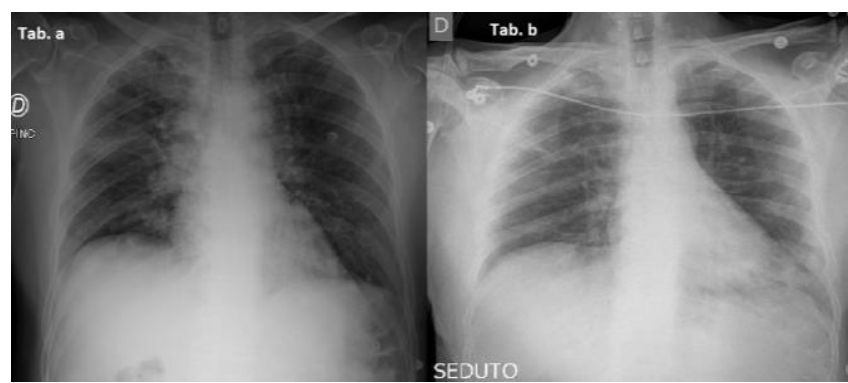

Figure 1: Chest $X$-ray executed on day 1 of admission in the supine position (a), second chest $X$-ray executed on day 8 in the sitting position (b)

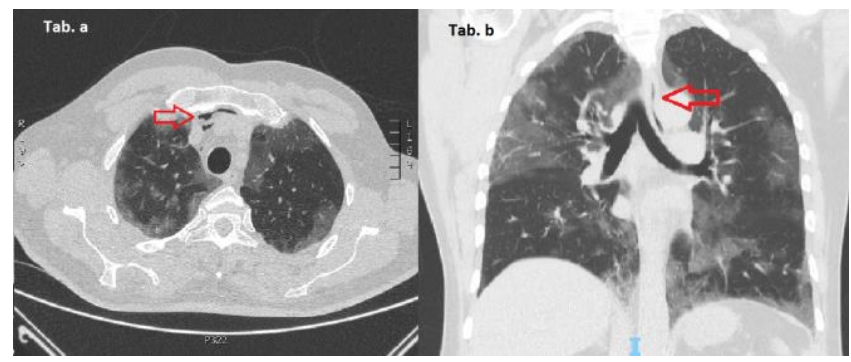

Figure 2: Chest CT-angiography executed on day 8 of admission; axial scanning plane (a) and coronal scanning plane (b). The red arrow indicates an upper pneumomediastinal leak in the anterior mediastinum

A chest $\mathrm{X}$-ray revealed parenchymal thickening in the right middle lung field and accentuated broncho-vascular markings (signs compatible with interstitial pneumonia) (Figure 1a), and the patient was subsequently admitted to our Internal Medicine department dedicated to COVID inpatients.

Steroid therapy with dexamethasone was administered starting on the first day at a dose of $6 \mathrm{mg} /$ day together with low molecular weight heparin (LMWH) at a prophylactic dosage; empiric oral treatment for the persistent dry cough with dihydrocodeine was also administered, together with acetylcysteine and PPI. In line with regional and local guidelines criteria, we decided to treat the patient with Tocilizumab, an immunosuppressive drug that is used mainly for the treatment of rheumatoid arthritis to reduce the hyperinflammatory response to SARS-CoV2(15).

The patient was placed on low-flow oxygen therapy with simple face mask until day $7 . \mathrm{SpO}_{2}$ was within the 94 $96 \%$ range for the duration of observation. The patient remained apyretic, and was advised to sleep in the prone position at night. Other vital parameters (blood pressure, respiratory rate and heart rate) also remained within the normal ranges. An arterial blood examination was repeated on the 3rd and 7th days with similar $\mathrm{PaO}_{2} / \mathrm{fiO}_{2}$ ratios (196 with $\mathrm{fiO}_{2} 33 \%$, and 173 with $\mathrm{fiO}_{2} 37 \%$, respectively).
On day 8 following admission, we decided to increase the oxygen supply and to perform an arterial blood examination with 10 LPM and non-rebreather mask due to an increase in respiratory fatigue and lower $\mathrm{SpO}_{2}$ levels (92\% with an oxygen flow of 6 litres per minute, LPM, $\mathrm{fiO}_{2} 40 \%$ ), leading to a mild worsening of pulmonary gas exchange $\left(\mathrm{PaO}_{2} / \mathrm{fiO}_{2} 133\right.$ with $\left.\mathrm{fiO}_{2} 45 \%\right)$.

A chest $\mathrm{CT}$-angiography was performed to allow a better assessment of parenchyma involvement in the lung and to exclude signs of pulmonary embolism, revealing bilateral extended areas of parenchymal "ground glass" involvement in both the upper and lower lobes of the lungs, in addition to some areoles with a greater density that were suggestive of interstitial and alveolar pneumonia.

In contrast, a thorax study highlighted the presence of air within the adipose tissue of the anterior mediastinum with a $2 \mathrm{~cm}$ thick and $6 \mathrm{~cm}$ long air leak. Figure 2 shows the pneumomediastinal leak in the axial and coronal scanning planes ( $a$ and $b$, respectively).

We consulted hospital intensivists to decide upon the best course of treatment for our patient, who recommended only a conservative approach. For the better definition of the patient's healthcare pathway, we transferred him to our dedicated rooms with parameter monitoring systems where he again underwent a chest $X$-ray, revealing a slight extension of the interstitial involvement already described in the lower-left pulmonary field (Figure 1b). As a result of a progressive improvement in the patient's clinical condition, we were able to reduce oxygen support until complete weaning, and the patient was discharged from hospital on day 20.

\section{DISCUSSION}

SPM has already been associated with severe acute respiratory syndrome (SARS) with a prevalence of $11.6 \%$ in a Chinese study in 2004 (16).

A group of researchers from Mexico recently published a report on the frequency of SPM and the related risk factors in a healthcare facility dedicated to COVID inpatients (17). Within a cohort of 271 patients, nine developed SPM (3.3\%), while four developed spontaneous pneumothorax (1.47\%). None of the patients received mechanical ventilation at the time of admission, although the authors did not clarify whether or not continuous positive airway pressure (CPAP) or high flow nasal cannulas (HFNC) were administered during hospitalization. The authors confirmed that SPM is not related exclusively to the mechanical ventilation of COVID-19 patients, and can involve subjects with risk factors such as young age, tobacco 
smoking, asthma and/or pulmonary emphysema, and the male gender. Similarly, Jones et al., in their study of 83 critically ill COVID inpatients, found that seven patients developed pneumomediastinum, with a prevalence of $8.4 \%$, and all were reported to develop pneumomediastinum after CPAP or non-invasive ventilation (NIV) therapy were administered.

Pneumomediastinum can also occur independently of assisted ventilation, and although it is rarely reported among non-ventilated COVID inpatients, previous studies have described it as a possible complication in patients with Severe Acute Respiratory Syndrome (SARS), leading to poor outcomes.

In general, SPM has a reported incidence in non-COVID patients of 1 in 25,000, and is more common in males and children (7). The exact prevalence of SPM in COVID patients is not known, and literature contains only a few some case reports. Consequently, it is necessary to identify the precise cause of cases occurring independently of mechanical invasive ventilation or non-invasive ventilation. In our case, the patient was treated only with low-flow oxygen, aside from in the few hours preceding the chest CT-angiography, when he was treated with 10 LPM via a reservoir mask. The patient was not placed on high-flow oxygen therapy, nor did he need non-invasive ventilation until complete oxygen weaning.

\section{CONCLUSION}

Spontaneous pneumomediastinum is still a rare complication in COVID-19 patients, and occurs with more frequency in patients on high-flow oxygen therapy or those being ventilated, even non-invasively. In other conditions, as happening for patients receiving low-flow oxygen therapy without being ventilated, only a few cases were described and often with poor outcomes, even if the underlying causes of the development of SPM are still unknown. As is the case for other complications related to COVID19, further studies of the topic are needed.

\section{ACKNOWLEDGMENTS}

We would like to give our sincere thanks to all the members of the medical staff that continue in their fight against this pandemic; to our colleagues, who gave their help during the hardest days of work, "re-inventing" themselves professionally, day by day; to all the extremely skillful and valuable nursing staff members; and to our assistance personnel, who return to the frontline every day.

\section{CONFLICTS OF INTEREST}

None declared.

\section{AUTHOR CONTRIBUTIONS}

Concept - S.G., E.G., G.L.C., N.G., P.S., M.T.M., G.M., A.L., E.M., R.D., E.P., L.M.; Planning and Design - S.G., E.G., G.L.C., N.G., P.S., M.T.M., G.M., A.L., E.M., R.D., E.P., L.M.; Supervision - S.G., E.G., G.L.C., N.G., P.S., M.T.M., G.M., A.L., E.M., R.D., E.P., L.M.; Funding - E.P., L.M.; Materials - S.G., M.T.M., G.M., E.P., L.M.; Data Collection and/or Processing - S.G., E.G., G.L.C., N.G., G.M., R.D.; Analysis and/or Interpretation - S.G., P.S., G.M., E.P., L.M.; Literature Review - S.G., P.S., E.P., L.M.; Writing - S.G., E.P., L.M.; Critical Review - P.S., E.P., L.M.

\section{YAZAR KATKILARI}

Fikir - S.G., E.G., G.L.C., N.G., P.S., M.T.M, G.M., A.L., E.M., R.D., E.P., L.M.; Tasarım ve Dizayn - S.G., E.G., G.L.C., N.G., P.S., M.T.M., G.M., A.L., E.M., R.D., E.P., L.M.; Denetleme - S.G., E.G., G.L.C., N.G., P.S., M.T.M., G.M., A.L., E.M., R.D., E.P., L.M.; Kaynaklar - E.P., L.M. Malzemeler - S.G., M.T.M., G.M., E.P., L.M.; Veri Toplama ve/veya iş̧leme - S.G., E.G., G.L.C., N.G., G.M., R.D.; Analiz ve/veya Yorum - S.G., P.S., G.M., E.P., L.M.; Literatür Taraması - S.G., P.S., E.P., L.M.; Yazıyı Yazan S.G., E.P., L.M.; Eleştirel İnceleme - P.S., E.P., L.M.

\section{REFERENCES}

1. World Health Organization. Naming the coronavirus disease (COVID-19) and the virus that causes it. World Health Organization 2020.

2. Zhang $W$, Zhao $Y$, Zhang $F$, Wang $Q$, Li T, Liu Z, et al. The use of anti-inflammatory drugs in the treatment of people with severe coronavirus disease 2019 (COVID19): The experience of clinical immunologists from China. Clin Immunol 2020; 214:108393. [CrossRef]

3. Channappanavar R, Perlman S. Pathogenic human coronavirus infections: causes and consequences of cytokine storm and immunopathology. Semin Immunopathol 2017; 39:529-39. [CrossRef]

4. Li Y, Xia L. Coronavirus disease 2019 (COVID-19): Role of chest CT in diagnosis and management. Am J Roentgenol 2020; 214:1280-6. [CrossRef]

5. Tenda ED, Yulianti M, Asaf MM, Yunus RE, Septiyanti W, Wulani $V$, et al. The Importance of chest CT scan in COVID-19. Acta Med Indones 2020; 52:68-73. 
6. Yang Q, Liu $Q, X \cup H$, Lu H, Liu S, Li H. Imaging of coronavirus disease 2019: A Chinese expert consensus statement. Eur. J. Radiol. 2020; 127:109008. [CrossRef]

7. Kouritas VK, Papagiannopoulos K, Lazaridis G, Baka S, Karavasilis V, Lampaki $S$, et al. Pneumomediastinum. J Thorac Dis 2015; 7(Suppl. 1):S44-9. [CrossRef]

8. Alavian N, Stephens JR, DeWalt DA. Spontaneous pneumomediastinum in a patient with COVID-19 pneumonia. J Gen Intern Med 2021; 1-2. [CrossRef]

9. Chekkoth SM, Supreeth RN, Valsala N, Kumar P, Raja RS Spontaneous pneumomediastinum in $\mathrm{H} 1 \mathrm{Nl}$ infection: uncommon complication of a common infection. J R Coll Physicians Edinb 2019; 49:298-300. [CrossRef]

10. Zhang $X$, Wang J, Zeng $Q, W_{U} X$, Jiang S, Shen J. Spontaneous pneumomediastinum and subcutaneous emphysema in avian influenza A (H5N6) human pneumonia. Clin Case Rep 2019; 7:2594-5. [CrossRef]

11. Tutor JD, Montgomery VL, Eid NS. A case of influenza virus bronchiolitis complicated by pneumomediastinum and subcutaneous emphysema. Pediatr Pulmonol 1995; 19:393-5. [CrossRef]

12. Graham CA, Ong YS. Hamman sign. Can J Emerg Med 2010; 12:63. [CrossRef]

13. Macklin MT, Macklin CC. Malignant interstitial emphysema of the lungs and mediastinum as an important oc- cult complication in many respiratory diseases and other conditions: An interpretation of the clinical literature in the light of laboratory experiment. Med. (United States) $1944 ; 23: 281-358$. [CrossRef]

14. Mitsunaga T, Hasegawa I, Uzura M, Okuno K, Otani K, Ohtaki $Y$, et al. Comparison of the National Early Warning Score (NEWS) and the Modified Early Warning Score (MEWS) for predicting admission and in-hospital mortality in elderly patients in the pre-hospital setting and in the emergency department. PeerJ 2019; 7:e6947. [CrossRef]

15. Abani $O$, Abbas A, Abbas F, Abbas M, Abbasi S, Abbass $H$, et al. Tocilizumab in patients admitted to hospital with COVID-19 (RECOVERY): a randomised, controlled, open-label, platform trial. Lancet 2021; 397:1637-45. [CrossRef]

16. Chu CM, Leung YY, Hui JYH, Hung IFN, Chan VL, Leung WS, et al. Spontaneous pneumomediastinum in patients with severe acute respiratory syndrome. Eur Respir J 2004; 23: 802-4. [CrossRef]

17. Rodriguez-Arciniega TG, Sierra-Diaz E, Flores-Martinez JA, Alvizo-Perez ME, Lopez-Leal IN, Corona-Nakamura $\mathrm{AL}$, et al. Frequency and risk factors for spontaneous pneumomediastinum in COVID-19 patients. Front Med (Lausanne) 2021; 8:662358. [CrossRef] 